\title{
Occurrence of a New Type of Pseudomonas syringae pv. actinidiae Strain of Bacterial Canker on Kiwifruit in Korea
}

\author{
Young Jin Koh', Gyoung Hee Kim¹, Hyun Seok Koh², Young Sun Lee ${ }^{2}$, Seong-Cheol Kim ${ }^{3}$ and Jae Sung Jung ${ }^{1 *}$ \\ ${ }^{1}$ Department of Plant Medicine; ${ }^{2}$ Department of Biology, Sunchon National University, Suncheon 540-742, Korea \\ ${ }^{3}$ Agricultural Research Center for Climate Change, NIHHS, RDA, Jeju 690-159, Korea \\ (Received on May 16, 2012; Revised on July 1, 2012; Accepted on July 17, 2012)
}

\begin{abstract}
Pseudomonas syringae pv. actinidiae strains, the causal agents of bacterial canker on kiwifruit, were isolated from Korea and Italy in 2011. Among 87 isolates, a total of six representative strains, three from Korea and three from Italy, were identified on the basis of biochemical and physiological tests. Identities were confirmed by PCR using $P$. syringae pv. actinidiae-specific primers PsaF1/R2, which amplified a 280-bp DNA fragment. The strains isolated from Korea in this study displayed BOX-PCR patterns similar to those isolated from Italy but different from those isolated previously in Korea or the pathotype $P$. syringae pv. actinidiae strain. The effector hopA1 and hopH1 genes, which are known to be present in strains isolated recently from France and Italy, were also present in $P$. syringae pv. actinidiae strains, SYS1, SYS2 and SYS4, isolated from Korea in this work. However, no amplicons of the expected size were obtained from strains previously isolated from Korea and Japan. In addition, the Korean strains isolated in this work belonged to haplotype I for the $c$ ts gene identical to those strains isolated from recent outbreaks in Italy. These results suggest that $P$. syringae pv. actinidiae strains isolated from Korea and examined in this work are a new type of strain similar to those found from recent outbreaks in Italy. This is the first report on the occurrence of $c$ ts haplotype I strains of $P$. syringae pv. actinidiae affecting kiwifruit plants in Korea.
\end{abstract}

Keywords : bacterial canker, BOX-PCR, hopAl, hopH1, kiwifruit, Pseudomonas syringae pv. actinidiae

Bacterial canker of kiwifruit caused by Pseudomonas syringae pv. actinidiae was first reported in Japan (Takikawa et al., 1989) and was subsequently recorded in Korea (Koh et al., 1994) and Italy (Scortichini, 1994). The disease caused by $P$. syringae pv. actinidiae was also recently observed in

\footnotetext{
*Corresponding author.

Phone) +82-61-750-3616, FAX) +82-61-750-5469

E-mail)jjung@sunchon.ac.kr
}

kiwifruit-producing areas in Portugal (Balestra et al., 2010), Spain (Balestra et al., 2011), France (Vanneste et al., 2011c) and Turkey (Bastas and Karakaya, 2012). Although $P$. syringae pv. actinidiae is considered to be the most devastating disease affecting Actinidia deliciosa and $A$. chinensis in Japan and Korea (Koh et al., 1994, Koh et al., 2010; Serizawa et al., 1898), it caused only minor damage to A. deliciosa in Italy until 2008 (Scortichini, 1994). During spring 2008, however, P. syringae pv. actinidiae was observed in some A. chinensis orchards in central Italy and caused death of kiwifruit plants (Balestra et al., 2009; Ferrante and Scortichini, 2009), and similar outbreaks were found on $A$. deliciosa (Vanneste et al., 2010). A recent outbreak of bacterial canker is devastating the Italian kiwifruit industry. The strains isolated from recent outbreaks in Italy are different from those isolated before 2008, or from those isolated from Japan and Korea (Ferrante and Scortichini, 2010; Vanneste et al., 2010).

In the process of field surveys monitoring bacterial canker infection on kiwifruit, $A$. chinensis plants showing typical symptoms of bacterial canker were found at one orchard in Goheung region, Korea, and the strains were isolated from diseased plant samples. However, these strains were shown to not possess gene fragments of the $c f l$ gene coding for coronatine (Han et al., 2003) nor fragments of the tox- $\arg K$ gene cluster coding for phaseolotoxin (Sawada et al., 2002), which were retained by the Korean strains and pathotype strain isolated from Japan, respectively (data not shown). In this work, these pathogens were compared with P. syringae pv. actinidiae strains previously isolated from Korea as well as the strains isolated from the recent outbreaks in Italy using a molecular approach.

The diseased plant samples of $A$. chinensis collected from Goheung region, Korea along with the plant samples of $A$. deliciosa from the province of Lazio, central Italy were processed to identify the causal agent of bacterial canker. Isolation and identification of pathogens were conducted according to previously described methods (Koh et al., 2010). A total of 87 isolated strains of $P$. syringae pv. actinidiae, 12 strains from Korea and 75 strains from Italy 
were obtained. Organisms were positive for levan production but negative for oxidase, potato soft rot and arginine dehydrolase, and they induced a hypersensitive response in tobacco leaves. Thus, they belonged to the P. syringae group Ia of LOPAT tests (Lelliott et al., 1966). Further, they did not produce fluorescent pigments on King's B medium (King et al., 1954). Among them, six P. syringae pv. actinidiae strains were selected for pathogenesis testing and molecular characterization. Pathogenesis tests were performed with the isolated strains using pot-grown, 2-year-old healthy $A$. deliciosa plants. A bacterial suspension corresponding to $1-2 \times 10^{7} \mathrm{cfu} / \mathrm{ml}$ was inoculated onto twig wounded with a sterile scalpel. In addition, the leaves pricked by syringe needle were also inoculated by spraying. Control plants were wounded in the same manner and treated with sterile distilled water. Dark brown lesion surrounded by yellow halos on leaves and wilting of twigs were observed within 1 or 2 weeks of artificial inoculation, and re-isolations from infected plants yielded strains with the same characteristics, satisfying Koch's postulates.

The strains used in this study are presented in Table 1. Bacteria were routinely grown at $26^{\circ} \mathrm{C}$ on peptone-sucrose medium (20 g peptone, $20 \mathrm{~g}$ sucrose per 1 liter) in broth or solid state. Total DNA from bacteria was isolated using a genomic DNA extraction kit (Bioneer, Korea). Identi-

Table 1. List of strains of Pseudomonas syringae pathovars used in this study

\begin{tabular}{|c|c|c|c|c|}
\hline $\begin{array}{l}\text { Pseudomonas } \\
\text { syringae } \\
\text { pathovars }\end{array}$ & Strains ${ }^{\mathrm{a}}$ & Host plant & $\begin{array}{c}\text { Geographic } \\
\text { origin }\end{array}$ & Year \\
\hline \multirow[t]{10}{*}{ pv. actinidiae } & IHL1 & $\begin{array}{l}\text { Actinidia } \\
\text { chinensis }\end{array}$ & Italy & 2011 \\
\hline & IVZT1 & A. chinensis & Italy & 2011 \\
\hline & IKB4 & A. chinensis & Italy & 2011 \\
\hline & SYS1 & A. chinensis & Korea & 2011 \\
\hline & SYS2 & A. chinensis & Korea & 2011 \\
\hline & SYS4 & A. chinensis & Korea & 2011 \\
\hline & CJW3 & A. deliciosa & Korea & 1999 \\
\hline & JYG6 & A. deliciosa & Korea & 1999 \\
\hline & KW11 & A. deliciosa & Japan & 1984 \\
\hline & PaB1 & A. deliciosa & Japan & 1995 \\
\hline \multirow[t]{2}{*}{ pv. theae } & $\begin{array}{l}\text { LMG } \\
5092\end{array}$ & $\begin{array}{l}\text { Camellia } \\
\text { sinensis }\end{array}$ & Japan & 1970 \\
\hline & $\begin{array}{l}\text { MAFF } \\
302851\end{array}$ & C. sinensis & Japan & 1993 \\
\hline pv. syringae & $\begin{array}{l}\text { DSM } \\
10604\end{array}$ & Syringa vulgaris & UK & unknown \\
\hline
\end{tabular}

${ }^{a}$ Strain name beginning with MAFF was obtained from the gene bank of the Japanese Ministry of Agriculture, Forestries, and Fisheries. LMG, BCCM ${ }^{\mathrm{TM}} / \mathrm{LMG}$ Bacterial Collection. DSM, German Collection of Microorganisms and Cell Cultures. fication of the strains was confirmed by PCR amplification with the $P$. syringae pv. actinidiae-specific primers PsaF1 (5'-TTTGCTTTGCACACCCGATTTT-3') and PsaR2 (5'CACGCACCCTTCAATCAGGATG-3'), which yielded a $280 \mathrm{bp}$ band, according to the method described earlier (Rees-George et al., 2010; Vanneste et al., 2011b). These primers were designed to be complementary to a portion of the 16S-23S rDNA intertranscribed space region and are used to detect $P$. syringae pv. actinidiae specifically. Strains obtained from Korea and Italy were compared with $P$. syringae pv. actinidiae strains previously isolated from Korea as well as the pathotype strain by means of repetitive-sequence PCR using BOXA1R primer (5'CTACGGCAAGGCGACCTGACG-3') (Louws et al., 1994). The presence of effector gene hopAl was evaluated by PCR using the primers hopA1-F (5'-CGGCAAGAGGTACG AGATTC-3') and hopA1-R (5'-TTCAATGCCTTTAGCGT GTG-3') designed by Ferrante and Scotichini (2010). The presence of effector hopH1 gene was checked by PCR using the primers hopH1-F (5'-CGTCTCGATATCCAGGC ATC-3') and hopH1-R (5'-TTCAGCTCGGATGGAGTTCT$3 ')$ (Ferrante and Scotichini, 2011). The cts gene encoding citrate synthase was amplified using the primers cts-Fp (5'AGTTGATCATCGAGGGCGCWGCC-3) and cts-Rp (5'TGATCGGTTTGATCTCGCACGG-3'). This primer set produced a 445 bp amplicon by PCR (Sarkar and Guttman, 2004). DNA was amplified in a total volume of $50 \mu \mathrm{l}$ using a PCR Thermal Cycler (Takara Shozo, Japan). The reaction mixture contained $5 \mu \mathrm{l}$ of $10 \times$ buffer $(100 \mathrm{mM}$ Tris- $\mathrm{HCl}$, $\mathrm{pH} 8.0,500 \mathrm{mM} \mathrm{KCl}, 25 \mathrm{mM} \mathrm{MgCl} 2), 200 \mu \mathrm{M}$ of each deoxynucleoside triphosphate, 20 pmol of each forward and reverse primer, 2.0 U of Taq DNA polymerase (Bioneer, Korea), and $20 \mathrm{ng}$ of purified genomic DNA as template. The reactions were performed using the following program: initial denaturation at $94^{\circ} \mathrm{C}$ for $5 \mathrm{~min}$, followed by 30 cycles of denaturation at $94^{\circ} \mathrm{C}$ for $30 \mathrm{~s}$, annealing at following temperatures for $30 \mathrm{~s}$, and extension at $72{ }^{\circ} \mathrm{C}$ for $30 \mathrm{~s}$. Reactions were terminated after a final 5 min elongation step at $72^{\circ} \mathrm{C}$. The annealing temperatures used for PsaF1/R2, BOX-PCR, hopA1 F/R, hopH1 F/R and cts Fp/ Rp were $65,53,58,58$ and $56^{\circ} \mathrm{C}$, respectively. PCR product amplified using cst-Fp/Rp primers was purified with a PCR purification kit (Bioneer, Korea) and the nucleotide sequence was determined by SolGent Co. (Korea).

As shown in Fig. 1, the expected 280 bp product was amplified from the DNA of all $P$. syringae pv. actinidiae strains isolated from Korea and Italy as well as the pathotype strain, but not from $P$. syringae pv. syringae. When the primer pair PsaF1/R2 was used in previous works, a $280 \mathrm{bp}$ product was amplified specifically from the DNA of $P$. syringae pv. actinidiae and not from any 


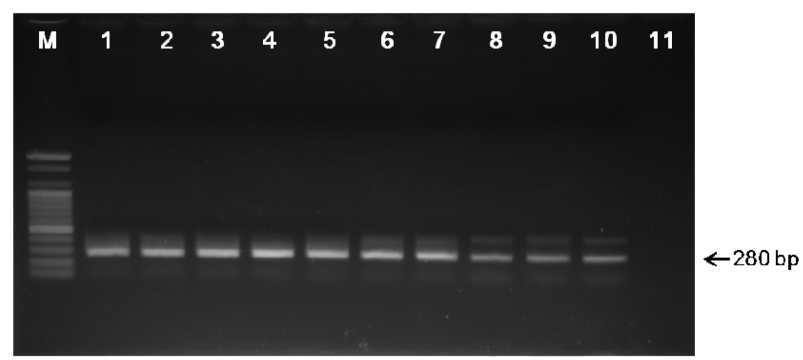

Fig. 1. Agarose gel electrophoresis after PCR using the primer PsaF1/R2 specific for Pseudomonas syringae pv. actinidiae. Lane M, 100-bp DNA marker (Bioneer); lanes 1-3, strains isolated from Italy in 2011 (IHL1, IVZT1, IKB4); lanes 4-6, strains isolated from Korea in 2011 (SYS1, SYS2, SYS4); lane 7, strain isolated from Korea in 1999 (CJW3); lane 8, strain isolated from Japan in 1984 (KW11); lanes 9-10, P. s. pv. theae strains (LMG 5092, MAFF 302851); lane 11, P. s. pv. syringae (DSM 10604).

other bacteria, except for the strains of $P$. syringae pv. theae (Rees-George et al., 2010; Vanneste et al., 2010). This primer set was not able to distinguish P. syringae pv. theae, which causes bacterial shoot blight in Camellia sinensis, from P. syringae pv. actinidiae, and it produced same-sized PCR products. However, as P. syringae pv. theae has been isolated only from tea plants and was shown to be specifically pathogenic only in host plants in inoculation tests (Scortichini et al., 2002), this result indicates that the strains isolated from kiwifruit in this work belong to $P$. syringae pv. actinidiae.

Some of the strains listed in Table 1 were assessed using BOXA1R primer in a repetitive PCR experiment. Box primer provided reproducible PCR profiles consisting of bands ranging in size from approximately $500 \mathrm{bp}$ to $5 \mathrm{~kb}$. The strains isolated from Korea in this work exhibited the same BOX-PCR electrophoretic patterns as the strains isolated from Italy in 2011, except for a $530 \mathrm{bp}$ band in the Korean strains (Fig. 2, lanes 1-6). However, the strains showed different PCR profiles from $P$. syringae pv. actinidiae CJW3 isolated from Korea in 1999 and the pathotype strain KW11 isolated from Japan in 1984 (Fig. 2, lanes 7,8). The genetic diversity between strains CJW3 and KW11 could be attributed to geographic origin as described by Scortichini et al. (2002). P. syringae pv. theae strain belonging to genomospecies 8, sensu Gardan et al. (1999) together with P. syringae pv. actinidiae and P. syringae pv. avellanae, showed different profiles with those of $P$. syringae pv. actinidiae (Fig. 2, lanes 9, 10). P. syringae pv. syringae showed a clearly distinct BOX-PCR pattern from those of $P$. syringae pv. actinidiae strains (Fig. 2, lane 11). In previous works, two different BOX-PCR patterns depending on isolation year were described for $P$. syringae pv. actinidiae strains (Ferrante and Scortichini, 2010; Vanneste et al., 2011a). It was shown that P. syringae pv.

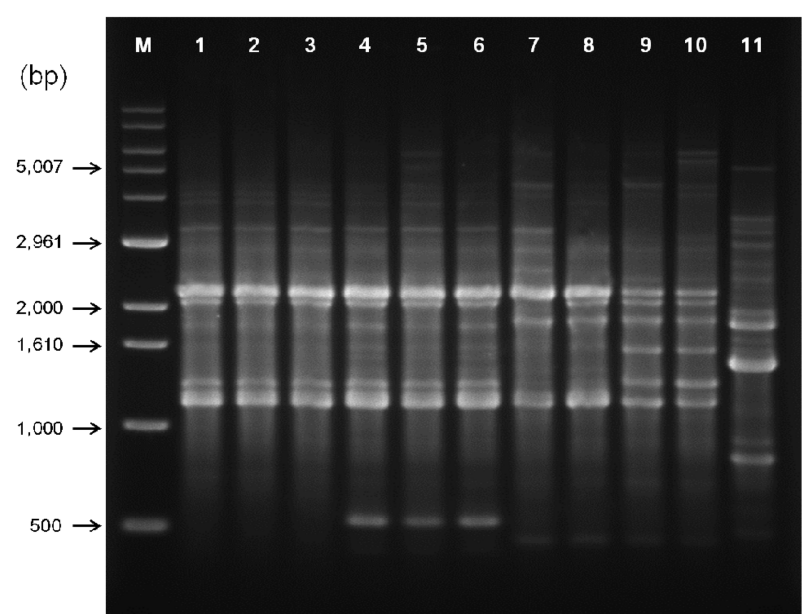

Fig. 2. Repetitive BOX-PCR fingerprinting patterns from genomic DNA of Pseudomonas syringae pv. actinidiae, P. s. pv. theae and P. s. pv. syringae. Lane M, 1-kb DNA marker (Bioneer); lanes 111 are the same as Fig. 1.

actinidiae strains obtained from Italy after 2008 possess different fingerprinting profiles from those previously isolated from Japan and Italy. Our data are in agreement with these reports. The strains isolated in this study were different from those isolated from past outbreaks of bacterial canker in Korea and Japan.

Ferrante and Scortichini (2010) evaluated the presence of 12 effector genes by PCR in P. syringae pv. actinidiae in order to differentiate the strains of recent outbreaks from those causing past epidemics in Japan and Italy. They subsequently checked the presence of 38 effector genes for strains of genomospecies 8, sensu Gardan et al. (1999), including $P$. avellanae, $P$. syringae pv. theae and $P$. syringae pv. actinidiae (Ferrante and Scortichini, 2011). Among the effector genes tested, hopAl and hopHI genes were detected in P. syringae pv. actinidiae isolated from Italy during 2008-9, but not in strains isolated from Japan and Italy in 1984 and 1992, respectively. Therefore, they concluded that hopAl and hopHl are unique to P. syringae pv. actinidiae strains of recent epidemics of bacterial canker on kiwifruits in Italy. This result, however, was challenged by Vanneste et al. (2011a), who found a DNA band of $441 \mathrm{bp}$ for the hopA1 in P. syringae pv. actinidiae strains which were isolated from Italy before 2008 . But they did not obtain the expected band with the Japanese or Korean strains examined. This is consistent with the results of this work. Primer set hopA1 F/R amplified an expected $441 \mathrm{bp}$ fragment from the DNA of strains isolated from Italy and Korea in 2011, but not from any of the Japanese or Korean strains obtained from past outbreaks (Fig. 3A). As the result published by Vanneste et al. (2011a), a slightly longer amplicon not related to the hopAl gene was obtained from some of the Korean and Japanese strains examined in this work (Fig. 3A, 


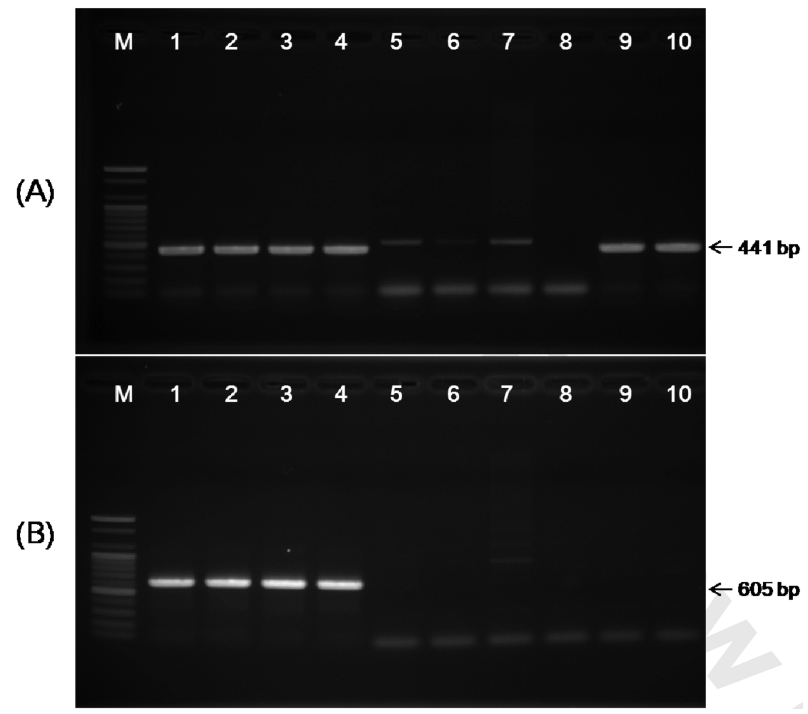

Fig. 3. Agarose gel electrophoresis of PCR products obtained by using primer sets to detect effector hopAl (A) and hopH1 (B) genes. Lane M, 100 bp DNA marker (Bioneer); lanes 1-4, Pseudomonas syringae pv. actinidiae strains isolated from Italy (IHL1, IVZT1) and Korea (SYS1, SYS2) in 2011; lanes 5-6, P. s. pv. actinidia strains isolated from Korea in 1999 (CJW3, JYG6); lanes 7-8, P. s. pv. actinidia strains isolated from Japan in 1984 (KW11) and 1995 (PaB1); lanes 9-10, P. s. pv. theae strains (LMG 5092, MAFF 302851).

lanes 5-7). This primer set also amplified an expected DNA fragment from P. syringae pv. theae (Fig. 3A, lanes 8, 9).

In contrast, the hopHl effector gene was shown to be unique to strains of recent epidemics in Italy (Ferrante and Scortichini, 2011). As shown in Fig. 3B an expected 605 bp band was amplified from all strains isolated in 2011 from Italy and Korea but no amplicon was found in the CJW3 and KW11 strains, which were isolated from Korea and Japan, respectively. This suggests that the strains isolated in this study from Korea are a new type of $P$. syringae pv. actinidiae. These primers did not produce an expected DNA fragment from $P$. syringae pv. theae.

The $c t s$ gene, which encodes a citrate synthesis, has been used in multi-locus sequence typing analysis of strains of Pseudomonas (Shark and Guttman, 2004). P. syringae pv. actinidiae strains are divided into two haplotypes, haplotype I and A, based on the DNA sequence of the $c t s$ gene (Vanneste et al., 2010). The two haplotypes differ by only two base pairs. In the haplotype I, cytosines are at positions 239 and 420, whereas in haplotype A, they are replaced by thymine and adenine, respectively. It was further found that the strains isolated from Italy since 2008 belong to cts haplotype I, whereas those from Japan, Korea, and Italy before 2008 are all cts haplotype A. The strains isolated in this work from Korea (SYS-1 and SYS-4) belonged to cts haplotype I, identical to those isolated from recent outbreaks in Italy (IMGL-1 and IK-B4), whereas the Korean (CJW3 and JYG6) and Japanese (KW11 and PaB1) strains isolated before belonged to cts haplotype A.

Based on these results, it appears that $P$. syringae pv. actinidiae strains isolated in this work from one kiwifruit orchard located in Goheung region, Korea, are cts haplotype I strains closely related to those recently isolated from Italy.

\section{Acknowledgements}

This study was carried out with the support of "Cooperative Research Program for Agriculture and Technology Development (PJ006686072012)", Rural Development Administration, Republic of Korea.

\section{References}

Balestra, G. M., Mazzaglia, A., Quattrucci, A., Renzi, M. and Rossetti, A. 2009. Current status of bacterial canker spread on kiwifruit in Italy. Aus. Plant Dis. Notes 4:34-36.

Balestra, G. M., Renzi, M. and Mazzaglia, A. 2010. First report of bacterial canker of Actinidia deliciosa caused by Pseudomonas syringae pv. actinidiae in Portugal. New Dis. Rep. 22:10.

Balestra, G. M., Renzi, M. and Mazzaglia, A. 2011. First report of Pseudomonas syringae pv. actinidiae on kiwifruit plants in Spain. New Dis. Rep. 24:10.

Bastas, K. and Karakaya, A. 2012. First report of bacterial canker of kiwifruit caused by Pseudomonas syringae pv. actinidiae in Turkey. Plant Dis. 96:452.

Ferrante, P. and Scortichini, M. 2009. Identification of Pseudomonas syringae pv. actinidiae as causal agent of bacterial canker of yellow kiwifruit (Actinidia chinensis Planchon) in central Italy. J. Phytopathol. 157:768-770.

Ferrante, P. and Scortichini, M. 2010. Molecular and phenotypic features of Pseudomonas syringae pv. actinidiae isolated during recent epidemics of bacterial canker on kiwifruit (Actinidia chinensis) in central Italy. Plant Pathol. 59:954-962.

Ferrante, P. and Scortichini, M. 2011. Molecular and phenotypic variability among Pseudomonas avellanae, $P$. syringae pv. actinidiae and $P$. syringae pv. theae: the genomospecies 8 sensu Gardan et al. (1999). J. Plant Pathol. 93:659-666.

Gardan, L., Shafik, H., Belouin, S., Brosch, R., Grimont, F. and Grimont, P. A. D. 1999. DNA relatedness among the pathovars of Pseudomonas syringae and description of Pseudomonas tremae sp. nov. and Pseudomonas cannabina sp. nov. (ex Sutic and Dowson 1959). Int. J. Syst. Bacteriol. 49:469-478.

Han, H. S., Koh, Y. J., Hur, J.-S. and Jung, J. S. 2003. Identification and characterization of coronatine-producing Pseudomonas syringae pv. actinidiae. J. Microbiol. Biotechnol. 13:110118.

King, E. O., Raney, M. K. and Ward, D. E. 1954. Two simple media for the demonstration of pyocianin and fluorescin. $J$. Lab. Clin. Med. 44:301-307. 
Koh, Y. J., Cha, B. J., Chung, H. J. and Lee, D. H. 1994. Outbreak and spread of bacterial canker in kiwifruit. Korean J. Plant Pathol. 10:68-72.

Koh, Y. J., Kim, G. H., Jung, J. S., Lee, Y. S. and Hur, J. S. 2010. Outbreak of bacterial canker on Hort16A (Actinidia chinensis Planchon) caused by Pseudomonas syringae pv. actinidiae in Korea. N. Z. J. Crop Hortic. Sci. 38:275-282.

Lelliott, R. A., Billing, E. and Hayward, A. C. 1966. A determinative scheme for the fluorescent plant pathogenic pseudomonads. J. Appl. Bacteriol. 29:470-487.

Louws, F. J., Fulbright, D. W., Stephens, C. T. and de Bruijin, F. J. 1994. Specific genomic fingerprints of phytopathogenic Xanthomonas and Pseudomonas pathovars and strains generated with repetitive sequences and PCR. Appl. Environ. Microbiol. 60:2286-2295.

Rees-George, J., Vanneste, J. L., Cornish, D. A., Pushparajah, I. P. S., Yu, J., Templeton, M. D. and Everett, K. R. 2010. Detection of Pseudomonas syringae pv. actinidiae using polymerase chain reaction (PCR) primers based on the 16S-23S rDNA intertranscribed spacer region and comparison with PCR primers based on other gene regions. Plant Pathol. 59:453464.

Sarkar, S. and Guttman, D. S. 2004. Evolution of the core genome of Pseudomonas syringae, a highly clonal, endemic plant pathogen. Appl. Environ. Microbiol. 70:1999-2012.

Sawada, H., Kanaya, S., Tsuda, M., Suzuki, F., Azegami, K. and Saitou, N. 2002. A phylogenomic study of the OCTase gene in Pseudomonas syringae pathovars: the horizontal transfer of the $\operatorname{argK-tox}$ cluster and the evolutionary history of OCTase gene on their genomes. J. Mol. Evol. 54:437-457.

Scotichini, M. 1994. Occurrence of Pseudomonas syringae pv. actinidiae on kiwifruit in Italy. Plant Pathol. 43:1035-1038.

Scortichini, M., Marchesi, U. and Di Prospero, P. 2002. Genetic relatedness among Pseudomonas avellanae, P. syringae pv. theae and P. s. pv. actinidiae, and their identification. Eur. J. Plant Pathol. 108:269-278.

Serizawa, S., Ichikawa, T., Takikawa, Y., Tsuyumu, S. and Goto, M. 1989. Occurrence of bacterial canker of kiwifruit in Japan: description of symptoms, isolation of pathogen and screening of bactericides. Ann. Phytopathol. Soc. Japan 55:427-436.

Takikawa, Y., Serizawa, S., Ichikawa, T., Tsuyumu, S. and Goto, M. 1989. Pseudomonas syringae pv. actinidiae sp. nov., the causal bacterium of canker in kiwifruit in Japan. Ann. Phytopathol. Soc. Japan 55:437-444.

Vanneste, J. L., Cornish, D. A., Yu, J., Audusseau, C., Paillard, S., Rivoal, C. and Poliakoff, F. 2011a. Presence of the effector gene hopAl in strains of Pseudomonas syringae pv. actinidiae isolated from France and Italy. N. Z. Plant Protec. 64:252258.

Vanneste, J. L., Giovanardi, D., Yu, J., Cornish, D. A., Kay, C., Spinelli, F. and Stefani, E. 2011b. Detection of Pseudomonas syringae pv. actinidiae in kiwifruit pollen samples. N. Z. Plant Protec. 64:246-251.

Vanneste, J. L., Poliakoff, F., Audusseau, C., Cornish, D. A., Pailard, S., Rivoal, C. and Yu, J. 2011c. First report of Pseudomonas syringae pv. actinidiae, the causal agent of bacterial canker of kiwifruit in France. Plant Dis. 95:1311.

Vanneste, J. L., Yu, J. and Cornish, D. A. 2010. Molecular characterization of Pseudomonas syringae pv. actinidiae strains isolated from the recent outbreak of bacterial canker on kiwifruit in Italy. N. Z. Plant Protec. 63:7-14. 